\title{
AntonioJ. BONOME
}

\section{Formal and Conceptual Border-Crossing in Crulic-drumul spre dincolo (Crulic-The Path to Beyond, 2011)}

\begin{abstract}
Anca Damian's film Crulic-drumul spre dincolo (Crulic-The Path to Beyond, 2011) may be a good example of form fitting content in the context of new Romanian cinema. The film makes use of a marginal medium as collage to cinematically document a real-life story producing a truly haunting mindscape; namely that of 33-year-old Romanian Claudiu Crulic, unfairly imprisoned in Krakow under a theft accusation. Crulic's passive resistance to transnational violence will emerge as a prolonged hunger strike with tragic consequences, and the film will show it by means of animation and collage. These are two art forms intimately associated with children that will gain a striking texture in the film through a skilled command of painting and other fine arts. This article aims to examine how traditional techniques are applied in the film to produce a compelling narrative involving the issue of migration in contemporary Europe. A comparative framework will be used to look at the film, with examples provided to clarify why Crulic deserves attention.
\end{abstract}

Keywords: Animation, Collage, Diary, Frontier, Immigration, Memory, Romanian, Passive resistance.

Antonio J. BONOME

Universidade da Coruña

antonio.bonome@udc.es

EKPHRASIS, $1 / 2020$

Poetics of the Borders: MeEting POINTSANDREPRESENTATIONALBORDERCROSSINGSINCONTEMPORARYCINEMA pp. 87-99

DOI: 10.24193/ekphrasis.23.7

Published First Online: 03 July 2020

\section{Spectrally, yours}

A dog barks, a crow cows, a telephone rings: Claudiu Crulic's voice initiates the narrative in extrema res, telling the viewer how his uncle learnt about Crulic's death. A thought-provoking connection between the crow as nature and the phone as technology is displayed here. It will be a pertinent one: the crow, an ominous being both in certain traditions and within the history of cinema, precedes and modifies the ambivalent image of a phone ringing. The subtext suggests the call brings 
bad news. In contrast with the techno-animist telephone, a single red rose lies in a vase just beside the telephone.

The room has been drawn with earth and grey colour washes. It looks cold, lonely (the single flower), while Claudiu's uncle, a thin bald man dressed in blue and grey strikes the viewer as a stoical solitary figure. This is clearly an animation film, but not exactly the happy type. There is more Adrian Ghenie than Walt Disney in its form and content.

Crulic's disembodied voice describes what is shown onscreen: the Romanian Consul in Warsaw is calling to report on Crulic's death. On top of the bad news, the lonely uncle learns that Claudiu Crulic's corpse will be cremated if a 2,500 Euro fee is not paid for repatriation purposes. Crulic's description of Consul's tone is not flattering: his impersonal ways verge on the offensive. Crulic's family travels to Poland to fetch the corpse and bring it back to Romania. Even though the music is gloomy, or precisely because of it, Crulic makes ironic remarks about his new luxurious Mercedes hearse and crisp new travel documents. Now he can cross the Polish and Ukrainian borders in style, go back home. The narrator is remarkable: not only a ghost, but one compiling and sharing information after his own death.

\section{Dirty brushwork tells the story}

After her feature debut Intalniri incrucisate (Crossing Dates, 2008), Anca Damian makes a dazzling foray into animation with Crulic-The Path to Beyond, a film that makes the most of humble materials and different media to present Claudio Crulic's modest origins, alienated youth, and tragic end. The extensive use of paper in this semi-documentary is not whimsical at all; paper provides the film with a tactile quality and an intimate distance on the proxemic level. Paper also means something as the most readily accessible and inexpensive art supply one can find. A quick visit to a paper and cardboard recycling container on any European street will confirm there is plenty of material to work with.

The use of loose colour washes on the different types of paper deploying the narrative makes the most of three basic elements: water, pigment, and paper. The watercolour technique suggests a formal and thematic discontinuity in this film: watercolours are traditionally used to paint dreamy bright landscapes, but in Crulic dark earth and cold greyish colour washes set the initial mood, which is not exactly a sunny one. A minimalistic colour palette is thoroughly explored to convey the inner and outer landscapes of Crulic's childhood. It is hard not to suggest warmth and intimacy when filming an animation on paper, yet the stark brushwork and complex neutral earths and greys chosen will provide a sombre contrast to said qualities. When too bright, a colour may be toned down by mixing it with a small amount of its complementary. According to traditional colour theory, complementary colours are set opposite each other in the colour chart. The complementary of a primary colour is obtained by mixing the remaining two primary colours. A full range of greys (and earths) may be produced by mixing a colour with its complementary. These rich neutral hues 
are usually discarded by novice painters as "muddy colours;" they are complex and difficult to use, something the animation team of Crulic is not afraid of. Furthermore, there is no need to use black to produce grey, just by adding white to any colour, different "greys" are produced, while expert painters can even produce "blue" without blue pigment. The visual artists who worked in Crulic knew about this, and the relevance of context, harmony, contrast, and perception. The balmy familiarity suggested by collage and animation is toned down by the muted colour palette; the combination invokes a set of complex emotions. Colour as understood in the film is capital to convey a realistic impression in representational painting. Colour (and its lack of) displays a strong emotive component in the film. It overpowers the representational aspect, which is achieved through other media.

The use of photography in combination with drawing is worth mentioning too; as shown by the scenes describing Crulic's childhood and youth, photographs add a functional contrast to the dirty brushwork and loose graphism. For instance, sketchy, broken, and nervous lines indicating tension or danger are paired with intimate photographic material so that the emotionally charged graphism will be nuanced by photographic verisimilitude. It is quite extraordinary how Crulic aims to convey truthfulness and realism using the media described so far. Such border-crossing to describe, precisely, border-crossing will be further developed in the formal and narratological planes.

\section{Pictures from a silent catastrophe}

Photographic material comes to the foreground with background drawings showing several clothes lines where photographs are pinned. Crulic's ghost reveals how his life could be described in a hundred photographs, and there is nothing extraordinary about that, or the domestic life shown by the pictures. The message here is less substantial than its enunciation: drawn clothes lines conjure a domestic environment while the narrator's voice and the photographs presented invoke an intimate distance. The scene feels like having Claudiu Crulic at your side while you look at his family photo album.

Photographs on watercolour backgrounds describe the main character's childhood in a "typically Romanian family" (07:37). Crulic was born in Dorohoi, near Moldavia, with Polish ascendency on his father's side. That seems not so typical and it brings to the fore the idea of unstable national identity. After his parents' divorce, Crulic will be constantly moving from a relative's home to the next, then to his father's (never to his mother's, which also seems unusual). These micro-migrations will be accepted by the young boy with a good measure of resignation and a budding alienation, or at least that might be inferred as he declares: "frankly speaking, I never had a proper family" (08:28), or "the closest relationship I had until I was five years old, was with a toy" (08:45).

Despite being constantly on the move between three homes, Crulic keeps fairly happy memories from his childhood. This is formally shown through brighter colours in the 
objects drawn, the jolly sound of farm animals on the spotless soundtrack, etc. There is no trace of criminality or violence in his family background, and if his spectre is to be believed, he was a well-adjusted individual to an honest rural environment in his early years. Claudiu Crulic was also a sensitive child, good-natured, fond of animals, and funnily courteous to young girls. To support this description, the author provides certain biographical details through the spectral narrator. For instance, when one of his dogs is poisoned by some neighbour because "she ate a couple chickens" (10:48), Crulic does not seek revenge or bear a grudge against the evil poisoner. Furthermore, the death of the other dog of old age "broke his heart" (11:20). This is how Crulic's childhood is presented to the viewer, who lacks the information required to confirm or deny its veracity. Considering the film is not only a semidocumentary but also an art film, it may be plausible to think there is some poetic licence in this first part of the narrative.

Cardboard cut-outs and clay animation are added to the film's visual resources to describe how Crulic drops out of high school. He will work as a mechanic until the economic situation in Romania worsens so much that he must migrate to Poland.

This second location marks an intermediate point in the story, here the conflict is presented, and two narrators will work alternatively to describe it. Visually speaking, the cumulative effect of different media used in telling the story is as striking as the capacity of the animation team to make it work. Video will be added as a new formal border-crossing to show how lively Krakow seems to Crulic the young immigrant.

In Krakow, he will live with an older man called Razdvanek, who "committed suicide a few months after my death" (19:13) and his girlfriend Lica, who bore him a child that was born dead. Red flowers fall over the child's corpse as Crulic declares "we buried him in Krakow" (19:44), and a crow caws (again). Lica, the girlfriend who "disappeared after my death" (19:49) plays an important role in Crulic's narration, precisely as an absence or omission.

Coming next, the sad details of the hero's early biography give way to a critical exposure of intra-European legal nastiness.

\section{Destiny is a plastic bag}

The autobiographical narrator describes a "New Europe" from a Romanian perspective when his country had barely joined the European Union. The new economic situation found our anti-hero living as a young proletarian in Poland and experiencing in his own skin the borders of a "Europe without frontiers." The new Europe is still reluctant to let Romania join the Schengen area.

The drama unfurls as Crulic is arrested in Krakow: "In 2007, in summer, I was accused of theft" (23:39). He will spend eight months in prison awaiting trial.

After returning to Romania and being advised by his relatives not to return to Poland, he decides to do it all the same, since "he was not going to hide from an offense he had 
not committed" (23:57). Border-crossing to go back to Poland marks the beginning of his undoing and shows a few remarkable spiritual traits in the protagonist: firstly, a sense of dignity, secondly, a certainty on his own innocence, and thirdly, a will to stand his own ground in the face of injustice. Crulic also displays a naive faith in technology (and its fair use by authorities): he trusts there will be video recordings showing "he was not the gypsy the shop owner described" (24:40).

After leaving Dorohoi for Krakow against his relatives' advice, he finally realizes "he was too optimistic" (24:34). Once again, the autobiographic narrator seems prone to selfdeception for - at least on a subconscious level - he was not optimistic at all regarding his return to Krakow: the screen shows his departure marked by a sinister sadness that brings him to tears. Penetration into the hero's psyche is conjured by an almost subliminal iteration of the image of a teddy bear being covered by a plastic bag. Crulic's apprehension is supported by said repetition (24:52), which in the context of his anguished departure infuses the sequence with a gloomy shade. He had previously mentioned in a light-hearted vein, how the bear looked like "a meat pack" under plastic (21:58), but now the bear does not look funny anymore.

Turning an everyday or neutral image into a disturbing omen by means of iteration and montage is not new. It is a well-known technique called the "Kuleshov effect" and it has also been used extensively not only in cinema but also in literature by writers as William S. Burroughs, whose disorienting ritornellos also border the subliminal and "have the effect of producing various forms of paramnesia" (Bonome 1).

Anca Damian's use of recurring images in Crulic is particularly subtle at times; the outstanding soundtrack is often determinant in adding new nuances to them.

Still images resurface with documentary force when Crulic's trial comes up; the viewers witness Claudiu's passport photograph on a file resting on the judge's desk (24:57). Attached to an official document, the photograph imparts a sense of reality to the scene. The trial does not go well, and on top of that, Crulic and his girlfriend Lica are harassed and photographed outside the courtroom by three plainclothes policemen (25:16). They also threaten them with further arrests should they appeal the judge's sentence. The policemen's cell phones are used to frame and coerce Crulic and Lica, which is quite a blow to Crulic's faith in technology; those photographs will precisely be instrumental in his forthcoming disgrace. Their threats will come true when Crulic is arrested one more time under a new theft accusation.

So far into the story it is hard to know who Crulic is, what moves him, or if the viewer is to believe his - at times - self-contradictory ghost. Detained now for questioning and under duress, Crulic fails to remember dates properly. You cannot get much more realistic than that when describing that kind of situation. He erroneously declares he was in Krakow when the theft occurred, while in fact he was on his way to Italy, where his girlfriend lived. After 
being sent to prison, Crulic starts a hunger strike that produces no reaction from neither the Romanian nor the Polish authorities: passive resistance will eventually define his spirit and destroy his body.

\section{Neither autobiography nor defacement}

In broad terms, Philippe Lejeune proposed in On Autobiography (1989) that autobiography should show an identity between author, narrator, and hero. Such identity is problematic if transposed from the literary to the cinematic in Crulic, whose author clearly is Anca Damian. The author will use a peculiar pseudo-autobiographic narrative mode to tell the story. Looking a little deeper into Lejeune's concept of autobiography, further complexities arise, since he defines it as a "retrospective prose narrative written by a real person concerning his own existence, where the focus is the individual life, in particular the story of his personality" (4).

Even if the Romanian actor Vlad Ivanov provides Crulic's voice with the proper regional accent and register required for a modicum of credibility, the story as told by the hero's ghost seems thin at times, or at least gives the impression of a crafty use of autobiography. That impression brings the shadow of paralipsis as a source of tension in the narrative, to the point that one starts questioning Crulic's tale, although the viewer is perfectly aware that the film is based on a true story. As understood by Gérard Genette, paralipsis "is the omission of some important action or thought of the focal hero, which neither the hero nor the narrator can be ignorant of but which the narrator chooses to conceal from the reader" (196).

Albeit some relevant pieces of information might be missing, sensing an untrustworthy narrator probably obeys more to a crafty use of autobiography by the author than to any possible concealment of information. The problem seems to be a narratological one, not one of lack of documentation or voluntary omission. Director Anca Damian has declared to have had access to some official documents pertaining the case and done extensive research on Crulic's case over "a year” (Rippa 1). It remains unclear if Damian had the opportunity to read whatever materials Crulic wrote while in prison. The film suggests that Crulic wrote many letters and a journal during his captivity.

\section{Paper and confinement}

Paper and writing seem to help Crulic in three ways: firstly, to avoid depersonalization and madness, secondly as a memory aid to recall the most minute details regarding his case, and thirdly and more importantly, all that letter writing and diary keeping help him to persevere. There is much information to ponder on in this writing compulsion. About diaries Philippe Lejeune comments:

We are not mendacious beings; we are narrative beings, constantly reconstructing the past in order to fit it into our plans for today's world. But even when guided 
by an ethical concern for truthfulness, that kind of reconstruction means flirting with invention. It seems to me that on that count, autobiography and the diary have opposite aims: autobiography lives under the spell of fiction; the diary is hooked on truth. (Diary 201)

It is worth mentioning that after almost three decades, Lejeune seems less uncompromising concerning the definition of autobiography. His distinction between autobiography and diary in terms of truthfulness may not be so clear-cut in Crulic since the viewer initially lacks the inside knowledge to know whether Crulic did really keep a journal while in prison or whether it is just another narrative device used by the author. On one hand, many pieces of information annotated in Crulic's diary match the information published by newspapers on his case at the time, so in a way, Crulic's prison diary is easier to believe than the story of his childhood and young adulthood as told by the first narrator. On the other hand, writing his own story was capital for Crulic, so an autobiographical narrator is a reasonable narrative tool and a legitimate focalization device. Regardless of Anca Damian's serious research on the subject, at the end of the film it is explained that parts of the narration are fictional (1:06:12). Even if perfectly permissible, that also unsettles (if slightly) the status of a narrative which strives towards documenting a grossly unfair real event. Conversely, although it is difficult to know which parts of the story are fictional, it is easy to find out which parts may be true; just by reading the newspapers describing the case one can get a reasonable idea of what really happened. For instance, periodicals show the film does not depart so much from the real story concerning a forthcoming location in Crulic's narrative: Montelupich detention centre(Fig. 1).

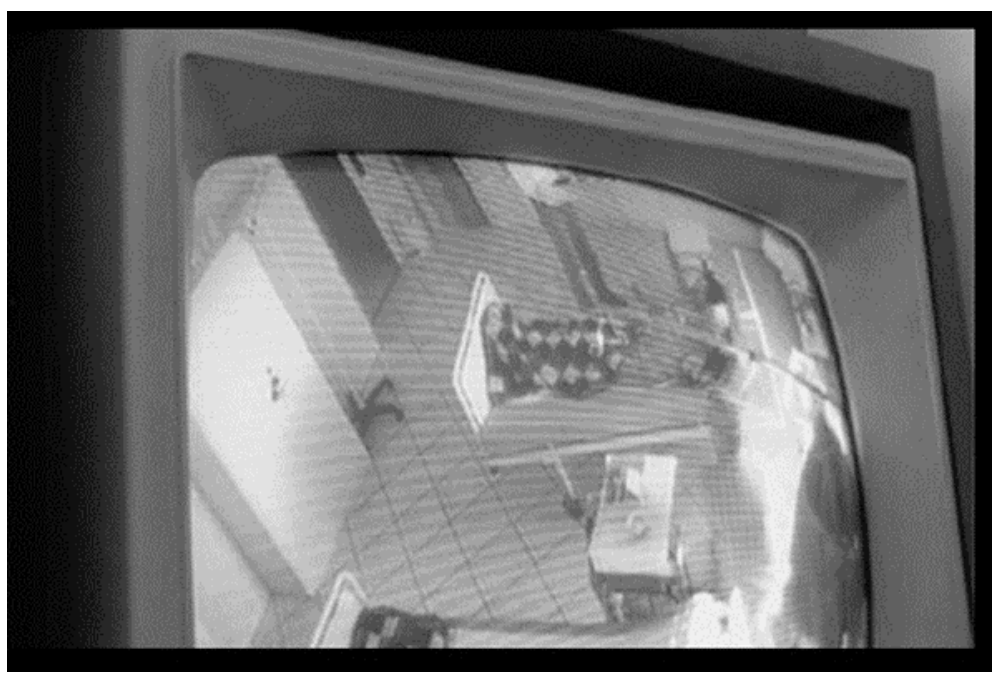

Fig. 1. Hospital monitor in Montelupich detention centre, Krakow. Photo: Grażyna Makara. Agencja Gazeta. 


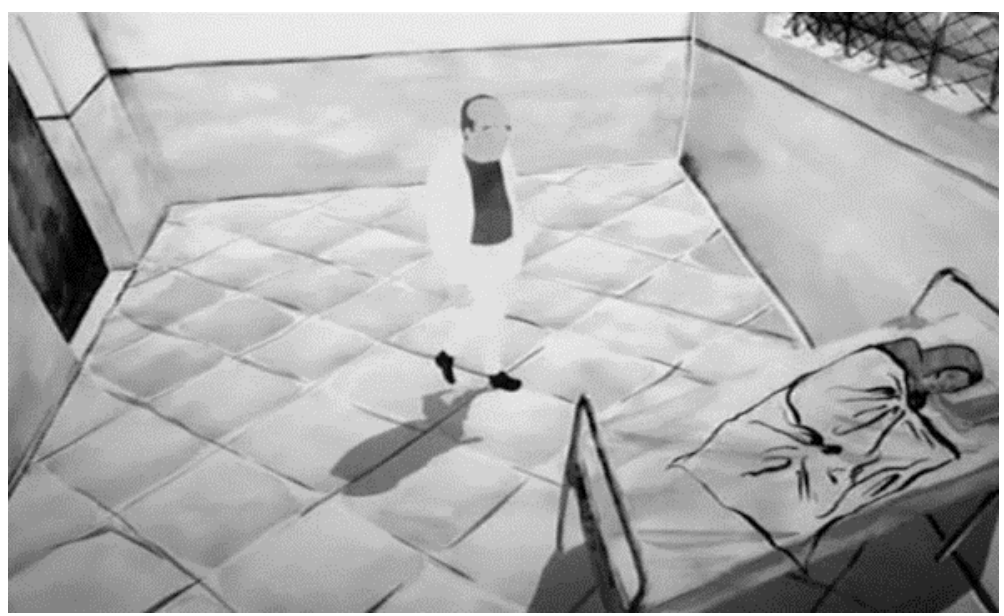

Fig. 2. Crulic-The Path to Beyond (53:44)

The fact that this animation film does indeed tell a true story brings the need to underplay the spectral narrator's unreliability, also in the context of autobiography as understood by Lejeune back in the day, which was probably too restrictive, but still useful. Paul de Man provided a less rigid theory of autobiography: "It appears, then, that the distinction between fiction and autobiography is not an either/or polarity but that it is undecidable (921). In any case, autobiography is but a narrative device in Crulic, while the question whether Claudiu Crulic's alleged diary made him an auto biographer or not remains open and brings food for thought into the "autofiction" debate.

Damian will change focalization on the second part of the film with a second narrator that will provide factual details pertaining to Crulic's second arrest. This change also involves proxemics: there is the impression of an increasing distance separating the viewer from the hero now. The soundtrack shows contents organized as in a newspaper article or a legal deposition, and conveys distance through tone and intonation on the second narrator's part, performed by Jamie Sives, who speaks English in a haunting and forensic manner:

"The life of Daniel Claudiu Crulic would've never become a story if a judge from the highest court of Poland hadn't had his wallet stolen. The theft took place in a branch of Zebra shoe shop in Krakow's main square on the 11th of July 2007. That same day 500 Euros were taken from the judge's bank account. There is more to Crulic's story than this. Back then, he and his girlfriend Lica Tomescu were suspects in a similar case. Two months later the victim from July saw some pictures of the two of them and declared that they were the ones responsible." (27:18)

This is the crux of the story, coupled with the fact that Crulic was not even in Krakow when the theft occurred. Now the film will show the underbelly of the Polish judicial system, and a manifest lack of goodwill in several EU countries towards immigrants coming 
from the East. The previous statement is not based on a personal impression; researcher Silvia Marcu has studied the frontier separating Romania, Moldova and Ukraine and shown how "Illegal immigration through Eastern Europe's frontiers has been prominent in the European debate prior to the EU's expansion towards Eastern Europe in 2004, followed in 2007 by the extension towards Romania and Bulgaria” (1). The issue of Romania and Schengen was a hot topic precisely at the time when Crulic was sent to prison.

Curiously enough, a third narrator will be exclusively devoted to describing a new location in the film: the prison of Montelupich (30:20). Such proliferation of narrators may deserve a similar evaluation as the wide range of media used in the film: it is odd, but somehow, it works. The third narrator sets the hero even further from the viewer: now Crulic will be behind prison walls. This new narrator speaks English with foreign accent and makes ironic comments about the prison's facilities. Such development may seem awkward to viewers unfamiliar with Eastern dry humour or the Polish prison system, but just a cursory search on the Internet may clarify this. The Polish periodical publication Tygodnik Powszechny broke the news about how Romanian officials had lied about Crulic's case in the article "Śmierć Po Rumuńsku” ("Death in Romanian”). The same periodical also published an article under the title "Nic nowego na Montelupich" ("Nothing new in Montelupich"), where the writer, who was under custody in that Polish prison in 1986, remembers events as dreadful as those shown in Crulic. So Anca Damian is making a very clear statement about the state of prisons in formerly communist countries, and by extension about the treatment of immigrants by two countries that provide many other nations with a steady flux of workers.

Of all the film reviews accessed to elaborate this brief analysis, only Alina Popescu dares to use the term "victim of migration" on her piece for the East European Film Bulletin, as she states "the status of the immigrant pauper ... is that of a double victim: of the country which he is leaving because of poverty but also of the destination country where he begins a new life by being a stranger, and thus a possible danger" (1).

Crulic starts a hunger strike on the first day of his imprisonment; this is quite unusual, especially considering he has been given a sentence of three months of preventive prison. The camera eye matches the narratological detachment with shots from above showing the hero on his bed in foetal position, dressed in a hoodie with his head covered to allow him sleep in the daylight.

Crulic's disembodied ghost hints at psychological torture exerted by the guards on the prisoner which the author is careful to laterally omit (again, paralipsis); the film will just show instead the prisoner's compulsory migration from cell to cell reminiscent of Crulic's constantly moving from one home to the next when he was a little child. Pace and rhythm are used more than correctly to display such events and convey a feeling of entrapment. 


\section{Melancholy and resistance}

Crulic's actions will define his character more precisely from now on. He will write countless letters to Polish and Romanian authorities; he will plead his innocence and beg for his case to be reopened, but his letters will either be ignored or met with patronising responses. The second narrator will mention the initial reaction of the Romanian Consul in Warsaw to Crulic's request for help; he will phone the Prosecutor's Office in Krakow concerning the case. A determinant phone call from the Detention Office in Krakow will inform the Romanian Consulate of Crulic's deteriorating condition and provoke no reaction from the Consul, whose personality is defined, in contrast to Crulic's, by inaction. Instead of making any advance to stop the situation, the Consul answers all the letters received from Crulic until then with a formulaic and shocking text: "we understand that during the entire duration of the investigation you have received fair treatment and that both your physical and mental health is good. We recommend that you place your trust in the Polish justice system which will surely rule in your favour if you are innocent" (40:53). It is the second narrator who provides this information, again in formal and detached English.

Crulic is taken to the psychiatrist, and later the first narrator declares "on October $12^{\text {th }}$, I refused to keep on using the Polish language" (41:34). According to his ghost, he was having a hard time understanding the language and feared giving wrong answers when questioned by the authorities. It is apparent in the film that Crulic kept a journal; it shows an elephant on its front cover, an animal renowned for its great memory (42:54). He is also shown using a calendar to avoid losing track of time (42:44), especially the date of his forthcoming trial.

As his case falls through the cracks of the system, the film shows Crulic's physical contours progressively disappearing while his features deteriorate and become corpselike. The soundtrack shows he has a hard time breathing. He is delirious and sees images of death, flashbacks of crows cawing, dead dogs, phantom teddy bears. Crulic will keep on writing while his health condition achieves a critical stage. The embassy does not answer his letters, and the prison staff keeps rotating him from cell to cell, a rhythm that stresses the impression of being caught by the wheels of a malignant machinery. On November 22, he refuses to move at all, he simply cannot do it anymore (46:03). It is the first narrator who informs the viewer of Crulic's determined path of resistance; he is now defined by a conscious and stubborn passivity, in short, he is a passive fighter and a heroic anti-hero.

The general attorney visits his cell with a translator on November 23 to conduct an interrogation, and Crulic will maintain his version of the story insisting that he was in Italy when the theft occurred. The second narrator steps in again to inform the viewer about the content of the legal proceedings which record Crulic's health state at the time of his interrogation: his health is "good", and no force-feeding is necessary according to the prison's medical staff. Doctors working at the prison will also be complicit and determinant in the ensuing scandal and public outrage concerning Crulic's case, their featureless faces are 
formally described by the animation team in a similar vein as the legal system's minions: cold, impersonal, casually heartless. That is partially confirmed by the website Romania-insider. com, which published that "three Polish physicians were prosecuted for serious neglect" (1).

Further inquiries were made by the prosecutor to the border police to ascertain whether Crulic's alibi was sound or not, but their reply was useless: "they no longer kept such information" (47:58). Still, the travel agency did confirm that Crulic's ticket to Italy had been paid for and there was a remarkably high possibility that he did travel to Italy during the dates in question. Even so, the prosecutor will not go further into it and declare that line of enquiry "irrelevant to the case" (48:17).

From now on, 'kafkian' is the best adjective to describe Crulic's situation; his preventive prison term is done, but he still remains incarcerated. A letter from the Embassy arrives one month late: it shows how he is being clearly neglected and ignored by the authorities. The second narrator resurfaces to confirm how Crulic's preventive detention of three months has now been extended by two more months, which is like a death sentence given his calamitous physical condition (49:32).

Crulic daydreams beautiful scenes where his young self runs free. Formally described as a happy line drawing or a childhood photocollage, it is here that the animators' performance shines, the evocative images merging with the excellent music by Piotr Ziubek. The beauty of the snowy landscapes dreamed by our (anti)hero is pierced by the sound of a cawing crow as the second narrator declares "his days are numbered" (54:16). The impersonal narrator will also describe Crulic's final days after the court's decision to force-feed him in view of his refusal to abandon his hunger strike. His body will be further damaged by a medical accident during the force-feeding process.

After all this Calvary, Crulic is released from the preventive detention centre. Real footage of an ambulance driving around the city is used to show this section, in combination with paper cut-outs and stop-motion animation. In hospital, unable to talk, and utterly withered, he will be visited one last time by the cawing crow before his final moments among the living. His death will be metaphorically represented by his shroud coming into life as he finally disappears. The anima transferred into the shroud will delicately move and "fly" to the beautiful music as Crulic's only way out of the system.

Finally, found footage will be shown of a bus driver confirming that Crulic did actually travel to Italy when the theft occurred; finding the driver was not so difficult after all. In fact, the periodical Tygodnik Powszechny published an article on 15 April 2008 under the title "Śmierć Pod Kontrolą" ("Death under Control”) revealing the identity of the bus driver: Sabina Ciepela, who declared she was not questioned by the prosecutor's office, which was informed by the travel agency in written formthat on 10 July 2007 Crulic had travelled to Italy. Only public outrage, and not shame, will compel the Romanian Minister for Foreign Affairs Adrian Cioroianu to do something about his blatant failure and extend his resignation. 


\section{The bigger picture}

Crulic-The Path to Beyond (2011) is the first Romanian animation long feature after two decades of inactivity since the last studio closed in the country. It is a film about being Romanian in the New Europe. The film tells a sad story with a bitter strain of black humour, which is part of the aesthetic described three years later in Doru Pop's monograph Romanian New Wave Cinema (Wave 4).

Crulic does share many thematic features shown by films tagged by Doru Pop as "New Romanian Cinema" as early as 2010 in his article "The Grammar of New Romanian Cinema." For instance, "the representation of conflicts with power institutions and the representatives of power" (12), is prominent in the film. Crulic also shares a rejection of socialist realism in favour of a verism which struggles against propaganda; how the third narrator ironically pitches the facilities of Montelupich to the viewers is a good example of that rejection. In Crulic, as in recent films from the "New Romanian Cinema," tension is often built around a trivial object or situation, but in Crulic that tension is achieved through iteration and montage. Considering structure in films studied by Pop's article, Crulic does not display the "unity of space and time" (25) shared by new Romanian films, nor does it share many of the structural features in those films as "long takes, fixed camera, Dogma 95 style of lighting, urban settings and minimalism of the storytelling" (24-5).

\section{A quirky emotional film that works}

Anca Damian does not follow in Crulic the structural trend displayed by directors as Mitelescu, Mungiu, Muntean, Porumboiu, or Puiu. The most remarkable trait in the animation team assisting Anca Damian lies in their versatility to artfully combine all kinds of media in a way it works when it is not supposed to. Some objections to the film could be made on the narratological plane, with an arguable autobiographical narrator that incidentally brings interesting issues for study, or the commercial-like section devoted to Montelupich brought by a third narrator that comes out of nowhere and disappears mysteriously. A masterful use of space initially suggests an intimate distance between the viewer and the antihero, with said distance progressively increased until the viewer finally "loses" Crulic as he crosses to the other side.

There is an insistence in Crulic to emotionally engage the viewer that is possibly detrimental to the verism intended by the film, even if that is also what makes it so engaging. A documentary on the same topic would certainly be more accurate and verisimilar but much less appealing. Such quirky features are in accord with the lo-fi, old-school animation and collage aesthetics that governs the film. In a similar fashion to the rich variety of media used, the narrator proliferation and emotional attachment somehow work.

Concerning imagery, if some motives as the crow are repeatedly used in the film almost to the point of being obsessive, they do also offer a glimpse of a spirituality which is clearly 
lacking in the European bureaucratic machinery. That lack or void is also expressed in the film by similarly repetitive routines as that of the prisoner being moved constantly from cell to cell. Such machinery seems to be humming the tune of spirituality being as futile as resistance to injustice. Claudiu Crulic proved with his life that tune to be wrong.

\section{Works Cited}

Bonome, Antonio José. "How Burroughs Plays with the Brain, or Ritornellos as a Means to Produce Déjà-Vu." CLCWeb: Comparative Literature and Culture, vol. 18, no. 5, 2016, doi: 10.7771/14814374.2962.

Damian, Anca. Crulic - Drumul Spre Dincolo. Aparte Film/Magellan Foundation, 2011.

De Man, Paul. “Autobiography as Defacement." MLN Comparative Literature, vol. 94 no.5, 1979, pp. 919-930.

Dobrowolski,Jerzy. “Nic Nowego Na Montelupich.” Tygodnik Powszechny, 8 April 2008, http://www. tygodnikpowszechny.pl/nic-nowego-na-montelupich-132211, accessed 24 June 2020.

Genette Gérard, et al. Narrative Discourse: An Essay in Method. Cornell UP, 2006.

Lejeune, Philippe. On Autobiography. Minnesota UP, 1989.

- On Diary. University of Hawaii, 2009.

Marcu, Silvia. "La Inmigración Irregular en Europa Oriental: La Frontera entre Rumanía, Moldavia y Ucrania." Análisis Del Real Instituto Elcano (ARI), no. 150, 2009.

Moldovan, Ioana. "Romanian Film Review: Based on A True Story- 'Crulic - The Path to Beyond."” Romania Insider, 3 October 2012, http://www.romania-insider.com/romanian-film-review-basedon-a-true-story-crulic-the-path-to-beyond, accessed 24 June 2020.

Nocuń, Małgorzata. "Śmierć Po Rumuńsku”. Tygodnik Powszechny, 1 April 2008, http://www. tygodnikpowszechny.pl/smierc-po-rumunsku-132301, accessed 24 June 2020.

Nocuń, Małgorzata. "Śmierć Pod Kontrolą". Tygodnik Powszechny, 15 April 2008, http://www. tygodnikpowszechny.pl/smierc-pod-kontrola-132149, accessed 24 June 2020.

Pop, Doru. "The Grammar of the New Romanian Cinema." Acta Univ. Sapientiae, Film and Media Studies, no. 3, 2010, pp. 19-40.

- Romanian New Wave Cinema: An Introduction. MacFarland \& Company, 2014.

Popescu, Alina. “Anca Damian's Crulic - The Path to Beyond (Crulic - Drumul Spre Dincolo, 2011)”. East European Film Bulletin, August 2012, http://eefb.org/perspectives/anca-damians-crulic-thepath-to-beyond-crulic-drumul-spre-dincolo-2011, accessed 24 June 2020.

Rippa, Roberto. “Anca Damian.” Rapporto Confidenziale, 9 Jan. 2012, http://www.rapportoconfi denziale.org/?p=16484, accessed 24 June 2020. 